\title{
Single and Mixed Phytoplasma Infections in Phyllody- and Dwarf-Diseased Clover Plants in Lithuania
}

\author{
Juozas B. Staniulis, Plant Virus Laboratory, Institute of Botany, Vilnius, Lithuania; Robert E. Davis, United States \\ Department of Agriculture-Agricultural Research Service (USDA-ARS) Molecular Plant Pathology Laboratory, \\ Beltsville, MD 20705; Rasa Jomantiene, Plant Virus Laboratory, Institute of Botany, Vilnius, Lithuania and \\ USDA-ARS Molecular Plant Pathology Laboratory; Audrone Kalvelyte, Laboratory of Gene Regulation, Institute \\ of Biochemistry, Vilnius, Lithuania; and Ellen L. Dally, USDA-ARS Molecular Plant Pathology Laboratory
}

\begin{abstract}
Staniulis, J. B., Davis, R. E., Jomantiene, R., Kalvelyte, A., and Dally, E. L. 2000. Single and mixed phytoplasma infections in phyllody- and dwarf-diseased clover plants in Lithuania. Plant Dis. 84:1061-1066.

Naturally diseased plants of clover (Trifolium spp.) exhibiting symptoms of clover phyllody (virescence and phyllody of flowers) or of clover dwarf (abnormally small leaves, shortened internodes, proliferation of shoots, and dwarf growth habit) were observed in fields in Lithuania. Phytoplasma group-specific polymerase chain reactions (PCRs) and restriction fragment length polymorphism (RFLP) analysis of $16 \mathrm{~S}$ rDNA revealed that the plants were infected by two mutually distinct phytoplasmas. Clover phyllody-diseased plants were infected by a subgroup 16SrI-C (subgroup I-C) phytoplasma (CPh-L) related to clover phyllody $(\mathrm{CPh}-\mathrm{C})$ phytoplasma in Canada. Clover dwarf-diseased plants were infected by both $\mathrm{CPh}-\mathrm{L}$ and a phytoplasma (CYEL) related to clover yellow edge $($ CYE-C) phytoplasma (subgroup 16SrIII-B = III-B) in Canada. A 1.8-kbp fragment of rRNA operon from CYE-L was amplified, cloned, and sequenced, and putative restriction sites mapped. This sequence shared high similarity $(99.7 \%)$ with that of CYE-C and exhibited no differences from CYE-C in RFLP patterns of 16S rDNA; therefore, we tentatively classified CYE-L in subgroup 16SrIII-B (type strain, CYE = CYE-C phytoplasma) of the $\mathrm{X}$-disease phytoplasma group. These findings extend the known geographical ranges of subgroup I-C and subgroup III-B taxa to the region of northern Europe including Lithuania and suggest a role of the subgroup III-B phytoplasma in clover dwarf disease.
\end{abstract}

Additional keywords: rRNA, Trifolium hybridum, T. pratense, T. repens

Several "yellows type" diseases of Trifolium spp. have been attributed to infection by phytoplasmas (formerly termed mycoplasmalike organisms, MLOs). Clover phyllody diseases are widespread and have been the most frequently reported phytoplasmal diseases of Trifolium spp. Clover phyllody has been described in regions including former Czechoslovakia (25), Canada (7), France (14,24), Italy (1,3), Romania (27,29), Germany (19), and Denmark (2). Additional clover and other legume diseases attributed to phytoplasmas

Corresponding author: R. E. Davis

E-mail: rdavis@asrr.arsusda.gov

GenBank Accession numbers of DNA sequences: AF173558 and AF175304.

Accepted for publication 20 June 2000.

Publication no. D-2000-0807-01R

This article is in the public domain and not copyrightable. It may be freely reprinted with customary crediting of the source. The American Phytopathological Society, 2000. include stolbur and parastolbur in former Czechoslovakia (36-39) and Romania $(26,28)$, clover dwarf in Lithuania $(13,35)$, clover yellow edge in Canada (8), clover proliferation in Canada (16), legume little leaf disease in Australia $(5,6)$, and witches' broom of alfalfa in Russia (23).

Phytoplasmas associated with diseases of clover in Canada and Italy have been classified according to analyses of conserved gene sequences. Based on analyses of 16S rRNA gene sequences, clover phyllody $(\mathrm{CPh})$ phytoplasma strains from Canada ( $\mathrm{CPh}-\mathrm{C} ; 22)$ have been classified in subgroup $\mathrm{C}$ of the aster yellows group (group 16SrI, subgroup C sensu Lee et al.; 22). Clover yellow edge (CYE) phytoplasma from Canada (CYE-C) has been classified in subgroup B of the X-disease phytoplasma group (group 16SrIII, subgroup $\mathrm{B}$ ); and clover proliferation $(\mathrm{CP})$ phytoplasma from Canada (CP-C) has been classified in subgroup A of the clover proliferation group (group 16SrVI). Phytoplasmas associated with clover phyllody in Italy belong to groups I and III (11). Prior to our study, phytoplasma strains associ- ated with other diseases of Trifolium spp., including clover dwarf, had not been characterized by molecular methods.

We have observed naturally diseased plants of $T$. repens exhibiting symptoms of clover dwarf disease throughout Lithuania since 1965. Plants of T. repens, T. hybridum, and $T$. pratense exhibiting symptoms of clover phyllody have similarly been observed throughout Lithuania during the same time period. Pathogen strains associated with the clover phyllody and clover dwarf diseases were transmitted to a wide range of plant species through the use of the parasitic plant dodder (Cuscuta sp.) or by leafhopper vectors (13; L. Genyte, unpublished Ph.D. thesis). The results from those experiments indicated that the clover phyllody and clover dwarf pathogens could be differentiated from one another on the basis of transmission characteristics, plant host range, and symptoms induced in plants. In the present study, we investigated naturally diseased plants of Trifolium spp. exhibiting symptoms typical of clover phyllody or clover dwarf in Lithuania. Our objectives were to confirm the association of phytoplasmas with these diseases and to determine the relatedness of the phytoplasmas to phytoplasmas found in clover and other plants elsewhere.

\section{MATERIALS AND METHODS}

Plant samples and reference phytoplasma strains. Samples of leaves were collected during August 1998 from eight naturally infected clover plants exhibiting symptoms of phyllody or dwarfing in Voke and Dotnuva, Lithuania (Table 1). One sample was taken from each plant. Phytoplasmas maintained in plants of periwinkle (Catharanthus roseus L. (G.) Don) and used as references included Canada peach $\mathrm{X}$-disease $(\mathrm{CX}), \mathrm{CYE}=\mathrm{CYE}-\mathrm{C}, \mathrm{CPh}=$ $\mathrm{CPh}-\mathrm{C}$, and $\mathrm{CP}=\mathrm{CP}-\mathrm{C}$ phytoplasmas, all of which originated in Canada (21).

Conditions and primers for polymerase chain reactions. Nucleic acid for use as a template in polymerase chain reaction (PCR) was extracted from plant tissue by a previously described method (22). After extraction, DNA was purified 
using a GeneCleanIII kit as specified by the manufacturer (BIO 101, Inc., Vista, CA).

Five pairs of oligonucleotide primers R16mF2/R16R1 (15), P1/P7 (10,33), and $\mathrm{R} 16 \mathrm{~F} 2 \mathrm{n} / \mathrm{R} 16 \mathrm{R} 2$ (15) were used to prime phytoplasma-universal amplification of ribosomal (r)RNA operon sequences R16(I)F1/R16(I)R1 (specific for group R16(III)F2/R16(III)R1 (specific for group 16SrIII phytoplasma rDNA) (20) were used to prime rDNA amplification in group-specific nested PCRs. In phytoplasma-universal nested PCRs, DNA amplified in PCR primed by $\mathrm{R} 16 \mathrm{mF} 2 / \mathrm{R} 1$ or by $\mathrm{P} 1 / \mathrm{P} 7$ was diluted 1:50 with sterile distilled water and used as a template in PCR primed by $\mathrm{R} 16 \mathrm{~F} 2 \mathrm{n} / \mathrm{R} 2$, which primes amplification of a segment of the $16 \mathrm{~S}$ rRNA gene approximately $1.2 \mathrm{kbp}$ in size. PCRs were carried out as previously described (18). In group-specific PCRs, DNA amplified in PCR primed by $\mathrm{R} 16 \mathrm{mF} 2 / \mathrm{R} 1$ or by $\mathrm{P} 1 / \mathrm{P} 7$ was diluted 1:50 with sterile distilled water and used as a template in PCR primed by R16(I)F1/R16(I)R1 or by R16(III)F2/R16(III)R1. Resulting PCR products were analyzed by electrophoresis through $1 \%$ agarose gel and stained with ethidium bromide, and DNA bands were visualized using a UV transilluminator. The DNA fragment size standard was a 1were used in PCRs. Primer pairs (rDNA) in nested PCRs. Primer pairs 16SrI phytoplasma rDNA) (20) and

kb ladder (Life Technologies, Gaithersburg, MD).

Restriction fragment length polymorphism analyses. Products from PCR primed by $\mathrm{R} 16 \mathrm{~F} 2 \mathrm{n} / \mathrm{R} 2$ were analyzed by single endonuclease enzyme digestion, according to the manufacturer's instructions, with $A l u \mathrm{I}, H h a \mathrm{I}, K p n \mathrm{I}$ (Life Technologies, Gaithersburg, MD), HaeIII, HinfI, HpaI, HpaII, MseI, RsaI, Sau3AI, and TaqI, (New England BioLabs, Beverly, MA). The restriction fragment length polymorphism (RFLP) profile of digested DNA was analyzed by electrophoresis through $5 \%$ polyacrylamide gel, staining in ethidium bromide, and visualization using a UV transilluminator. The DNA fragment size standard used was PhiX174 RF HaeIII digest (Life Technologies). RFLP patterns were compared with those obtained using the phytoplasmas in this study and with RFLP patterns previously published $(9,21,22,40)$. Phytoplasma 16S rRNA group and subgroup designations were based on RFLP analysis following the system of Lee et al. $(21,22)$.

Cloning of PCR products and screening of cloned rRNA operon sequences. We cloned phytoplasmal rDNA products, which had been amplified in direct (non-nested) PCRs primed by P1/P7, using the TOPO-TA PCR Cloning Kit (Invitrogen, Carlsbad, CA) according to the manufacturer's instructions. Recombinant plasmids were screened for the pres-

Table 1. Classification of phytoplasmas detected in diseased Trifolium spp. in Lithuania on the basis of results from restriction fragment length polymorphism (RFLP) analysis of 16S rDNA and amplification of $16 \mathrm{~S}$ rDNA in group-specific polymerase chain reactions

\begin{tabular}{lcccc}
\hline & & & \multicolumn{2}{c}{ 16S rRNA classification based on } \\
\cline { 4 - 5 } Plant no., species & Location $^{\mathbf{b}}$ & Symptoms $^{\mathbf{c}}$ & RFLP analysis & Group-specific PCR \\
\hline 1. T. repens & Voke & Phyllody & I-C & I \\
2. T. repens & Voke & Dwarf & I-C + III-B & I + III \\
3. . hybridum & Voke & Phyllody & I-C & I \\
4. T. repens & Dotnuva & Phyllody & I-C & I \\
5. T. repens & Dotnuva & Phyllody & I-C & I \\
6. T. repens & Dotnuva & Dwarf & I-C + III-B & I + III \\
7. T. hybridum & Dotnuva & Phyllody & I-C & I \\
8. T. pratense & Dotnuva & Phyllody & I-C & I \\
\hline
\end{tabular}

${ }^{\mathrm{a}} \mathrm{I}=$ group $16 \mathrm{SrI}$ (aster yellows phytoplasma group), $\mathrm{III}=$ group $16 \mathrm{SrIII}$ (X-disease phytoplasma group), I-C = subgroup C (clover phyllody phytoplasma subgroup) of group 16SrI. III-B, subgroup $\mathrm{B}$ (clover yellow edge phytoplasma subgroup) of group $16 \mathrm{SrIII}$. PCR $=$ polymerase chain reaction.

${ }^{\mathrm{b}}$ Location in Lithuania where plant sample was collected.

${ }^{c}$ Disease symptoms observed in plant indicated. ence of cloned rRNA operon fragments by amplification of DNA from recombinant plasmids in PCRs primed by $\mathrm{R} 16 \mathrm{~F} 2 \mathrm{n} /$ $\mathrm{R} 16 \mathrm{R} 2$ or by $\mathrm{P} 1 / \mathrm{P} 7$ followed by RFLP analysis of the amplified, cloned DNA. The RFLP profiles were compared with those obtained from analysis of amplified, uncloned rDNA products of PCRs containing template DNAs from phytoplasma infected plants.

Nucleotide sequencing and putative restriction site analysis. The sequences of a cloned fragment $(1.8-\mathrm{kbp})$ of the rRNA operon of CYE-L phytoplasma and a corresponding fragment of CYE-C phytoplasma were determined by automated sequencing and were deposited in the GenBank data library. Other phytoplasma $16 \mathrm{~S}$ rDNA sequences were obtained from GenBank. Sequences were aligned and sequence similarities evaluated by using the DNASTAR program Align option (DNASTAR, Inc., Madison, WI). Putative restriction site maps were generated by using the DNASTAR program MapDraw option.

Nucleotide sequence accession numbers. The GenBank accession numbers for the rRNA operon sequences of CYE-L, CYE-C, and other phytoplasma strains used in this study are listed in Table 2.

\section{RESULTS}

Symptoms in diseased plants of clover. Two symptom syndromes were observed among the eight plants of Trifolium spp. (clover) that were studied. Six plants exhibited virescence and phyllody of flowers, a syndrome typical of clover phyllody disease as previously described (7); the remaining two plants had abnormally small leaves, shortened internodes, proliferation of shoots, and compact, dwarf growth habit, a syndrome characteristic of a disease which we term clover dwarf (Fig. 1). This latter syndrome closely resembled that previously described for clover dwarf disease in Lithuania (35) and Czechoslovakia (37) and was similar in several respects to symptoms described for parastolbur disease of $T$. repens in Czechoslovakia (37).

Detection and classification of phytoplasmas using group-specific PCRs and RFLP analysis of amplified 16S rDNA.

Table 2. Sequence similarities among $16 \mathrm{~S}$ rDNAs of selected group 16SrIII phytoplasmas and the group 16SrI aster yellows phytoplasma

\begin{tabular}{lcccccc}
\hline & & \multicolumn{4}{c}{ Similarity with indicated phytoplasma 16S rDNA (\%) } \\
\cline { 4 - 7 } Phytoplasma $^{\mathbf{b}}$ & GenBank accession no. & CYE-C (III-B) & ICPh (III-B) & VacWB (III-B) & WX (III-A) & MIAY (I-B) \\
\hline CYE-L & AF173558 & 99.7 & 98.8 & 98.8 & 98.9 & 88.8 \\
CYE-C & AF175304 & & 98.7 & 98.7 & 98.8 & 88.8 \\
ICPh & X77482 & & & 97.7 & 98.0 & 87.9 \\
VacWB & X76430 & & & & 88.4 & 88.5 \\
WX & L04682 & & & & \\
\hline
\end{tabular}

a Similarity between comparable 1.5-kbp sequences was estimated using the Align option of DNASTAR program.

${ }^{\mathrm{b}}$ CYE-L = group III subgroup B clover yellow edge phytoplasma from dwarf-diseased plants of clover in Lithuania, CYE-C $=$ clover yellow edge phytoplasma from Canada, ICPh = Italian clover phyllody phytoplasma, VacWB = Vaccinium witches' broom phytoplasma from Germany, WX $=$ peach western X-disease phytoplasma, and MIAY = Michigan aster yellows phytoplasma (GenBank accession no. of DNA M30970). 16S rRNA restriction fragment length polymorphism group and subgroup are given in parentheses. 
Phytoplasmas were detected in all eight diseased plants on the basis of amplification of phytoplasmal 16S rDNA in nested PCR primed by phytoplasma universal primer pairs (Fig. 2). Products of PCR primed by $\mathrm{F} 2 \mathrm{n} / \mathrm{R} 2$ from all eight plants were subjected to RFLP analysis using 11 restriction enzymes. The RFLP patterns of $16 \mathrm{~S}$ rDNA indicated that the diseased Trifolium spp. plants were infected by two mutually distinct phytoplasmas (Table 1). Representative $K p n I$ and $A l u$ I RFLP patterns of rDNA amplified from seven plants are illustrated in Figures 3 and 4. The collective RFLPs of rDNA from five plants (numbered 1, 3, 5, 7, and 8) were indistinguishable from each other and from RFLP patterns previously published for rDNA from $\mathrm{CPh}-\mathrm{C}$ phytoplasma from Canada $(21,22)$. The results indicated that these plants, which exhibited symptoms characteristic of clover phyllody disease described in Canada (7), were infected by phytoplasma strains belonging to group I (aster yellows group), subgroup C (clover phyllody phytoplasma subgroup). The phytoplasmas detected in these five plants exhibited the same collective RFLP patterns; therefore, we consider them to be strains of a single phytoplasma which we designate clover phyllody phytoplasma-Lithuania $(\mathrm{CPh}-\mathrm{L})$. The sum of the sizes of rDNA fragments in the AluI (Fig. 4) and HaeIII and MseI (data not shown) RFLP patterns exceeded the size of $1.2 \mathrm{kbp}$ expected for a product of PCR primed by R16F $2 n$ / R16R2; we interpreted this pattern to indicate the presence of two sequence heterogeneous 16S rRNA genes in the $\mathrm{CPh}$ $\mathrm{L}$ phytoplasma, as previously interpreted (22) for $\mathrm{CPh}$ phytoplasma in Canada.
The collective RFLP patterns of $16 \mathrm{~S}$ rDNA from plants 2 and 6 indicated that both of these plants, which exhibited symptoms characteristic of clover dwarf disease, were simultaneously infected by two different phytoplasmas (Figs. 3 and 4). The DNA pattern was faint and is not visible for one of the two phytoplasmas in plants 2 and 6. The RFLP patterns, obtained by the use of 11 restriction enzymes (data from use of nine enzymes not shown), were compared with patterns previously published $(9,21,22,40)$ and with RFLP patterns of amplified 16S rDNA from $\mathrm{CPh}$ $\mathrm{C}, \mathrm{CP}, \mathrm{CYE}-\mathrm{C}$, and CX phytoplasmas used as controls (Figs. 3 and 4). Visual superimposition of the published $(20,22)$ and control RFLP patterns of rDNAs from $\mathrm{CPh}-\mathrm{C}$ and CYE-C phytoplasmas yielded RFLP patterns indistinguishable from those of rDNA amplified from plants 2 and 6. This result indicated that the RFLP patterns of rDNA from plants 2 and 6 could be interpreted as composites of the RFLP patterns of rDNAs from a CPh-C-related phytoplasma and a CYE-C-related phytoplasma. On the basis of these results, we tentatively concluded that plants 2 and 6 were infected by $\mathrm{CPh}-\mathrm{L}$ phytoplasma and a phytoplasma, which we designate clover yellow edgeLithuania (CYE-L), belonging to group III (X-disease phytoplasma group), subgroup B (CYE phytoplasma subgroup).

To confirm phytoplasmal infection of the Trifolium spp. plants, and to verify that the plants were infected by phytoplasmas affiliated with groups $16 \mathrm{SrI}$ and 16SrIII, we used PCRs primed by group-specific primers. Group I phytoplasma-specific DNA amplification was observed in PCRs containing template DNAs from all plants;

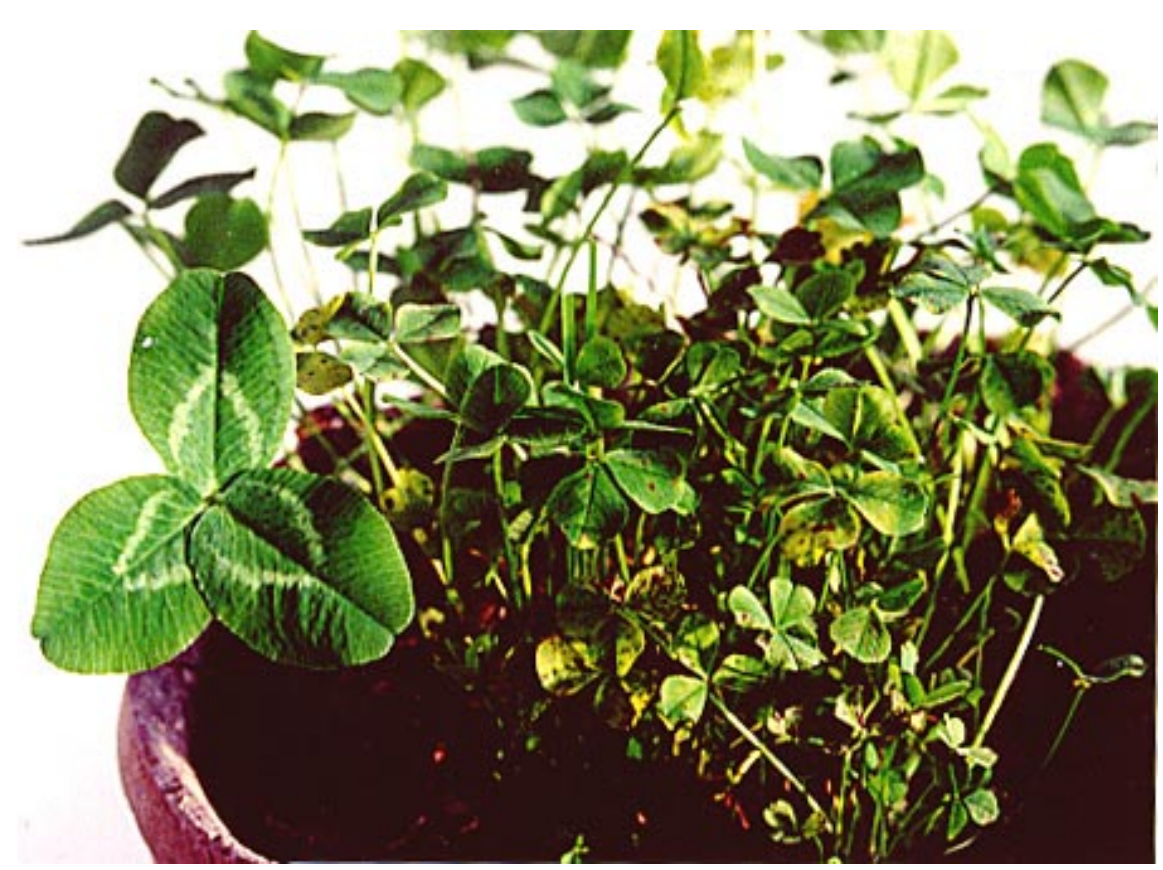

Fig. 1. Symptoms of clover dwarf disease in a naturally diseased plant of Trifolium repens (white clover) in Lithuania. Note abnormally small leaves on dwarf-diseased plant compared to large, normal leaf on left. group 16SrIII phytoplasma-specific DNA amplification was observed only in PCRs containing template DNAs from plants 2 and 6 (data not shown).

\section{SW 12345678 든잉 S}

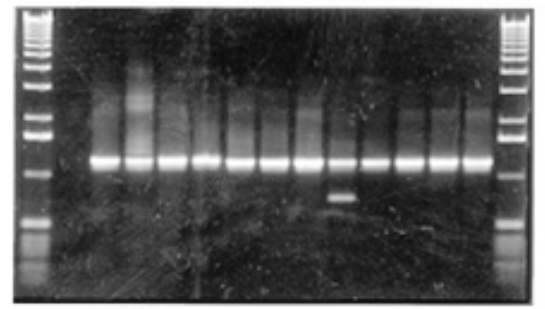

Fig. 2. Nested polymerase chain reaction (PCR) amplification of phytoplasma $16 \mathrm{~S}$ rDNA from naturally diseased plants of Trifolium spp. collected in the field in Lithuania. The first PCR was primed with primer pair $\mathrm{P} 1 / \mathrm{P} 7$, and this was followed by reamplification of target DNA in a nested PCR primed with primer pair F2n/R2. Lane S: 1-kbp size standard. Lane W: products of PCR that was devoid of template DNA. Lanes 1, 2, 3, 4, 5, 6, 7, and 8: products of PCRs that contained template DNAs derived from eight diseased plants of Trifolium spp. $T$. repens (lanes $1,2,4,5$, and 6), T. hybridum (lanes 3 and 7), and T. pratense (lane 8). CPh-C (clover phyllody), CYE-C (clover yellow edge), $\mathrm{CP}-\mathrm{C}$ (clover proliferation), and CX (Canada $\mathrm{X}$-disease): products of PCRs that contained template DNAs derived from reference phytoplasmas.
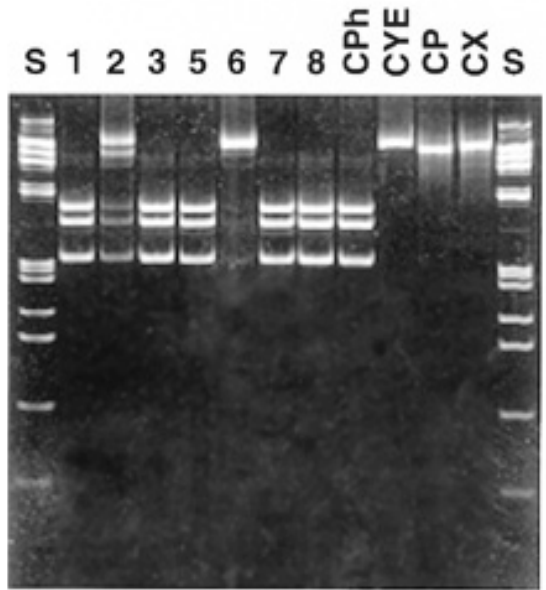

Fig. 3. $K p n I$ restriction fragment length polymorphism analysis of $16 \mathrm{~S}$ rDNAs amplified, in nested polymerase chain reactions (PCRs) primed by $\mathrm{F} 2 \mathrm{n} / \mathrm{R} 2$, from phytoplasma strains detected in diseased plants of Trifolium spp. in the field in Lithuania. Lane S contained PhiX 174 RFI DNA HaeIII digest; the fragment sizes in this lane were (from top to bottom) 1,353, 1,078, 873, 603, 310, 281, 271, 234, 194, 118, and $72 \mathrm{bp}$. Lane W: products of PCR that was devoid of template DNA. Lanes 1, 2, 3, 5, 6, 7, and 8: digests of DNAs amplified from diseased plants of Trifolium spp. and from CPh-C (clover phyllody), CYE-C (clover yellow edge), CP-C (clover proliferation), and CX (Canada X-disease) phytoplasmas. T. repens (lanes 1,2 , 5, and 6), T. hybridum (lanes 3 and 7), and $T$. pratense (lane 8 ). 
Nucleotide sequence of cloned rRNA operon fragment from CYE-L phytoplasma. The CPh-L phytoplasma was classified in group $16 \mathrm{SrI}$, subgroup $\mathrm{C}$, which apparently is found elsewhere in Europe (11); therefore, DNA from this phyto-
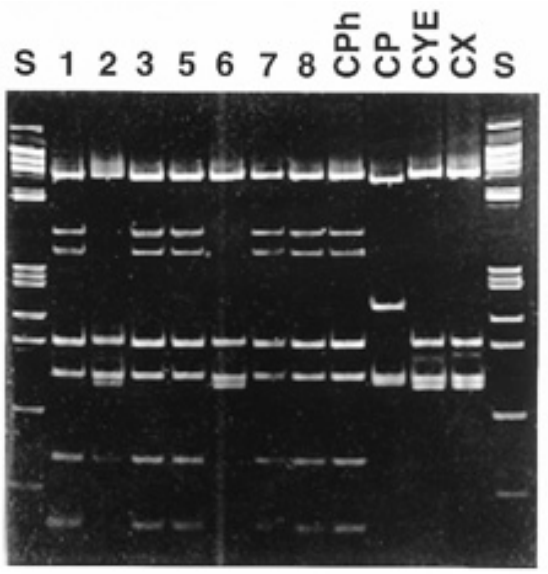

Fig. 4. AluI restriction fragment length polymorphism analysis of $16 \mathrm{~S}$ rDNAs from phytoplasma strains detected in diseased plants of Trifolium spp. in the field in Lithuania. DNA products from the nested polymerase chain reaction (PCR), primed with primer pair F2n/R2, were digested with restriction enzyme AluI. Lane S contained PhiX 174 RFI DNA HaeIII digest; the fragment sizes in this lane were (from top to bottom) 1,353, 1,078, 873, 603, 310, 281, 271, 234, 194, 118, and 72 bp. Lane W: products of PCR that was devoid of template DNA. Lanes 1, 2, 3, 5, 6, 7, and 8: digests of DNAs amplified from diseased plants of Trifolium spp. and from $\mathrm{CPh}-\mathrm{C}$ (clover phyllody), CYE-C (clover yellow edge), CP-C (clover proliferation), and CX (Canada X-disease) phytoplasmas. T. repens (lanes 1, 2, 5, and 6), T. hybridum (lanes 3 and 7), and $T$. pratense (lane 8 ). plasma was not subjected to nucleotide sequence analysis. Different group III phytoplasmas may occur in Europe (11); therefore, we determined the nucleotide sequence of a cloned 1.8-kbp fragment of the rRNA operon from CYE-L phytoplasma. Expected fragment sizes based on analysis of putative restriction sites were in excellent agreement with fragment sizes obtained by enzymatic RFLP analysis of amplified rRNA operon sequences from CYE-L phytoplasma and CYE-C phytoplasma (Fig. 5). CYE-L and CYE-C phytoplasmas were not distinguished from each other by this analysis. Italian clover phyllody (ICPh) phytoplasma differed from both CYE-L and CYE-C on the basis of putative restriction site analysis.

Sequence similarity of the cloned 1.8kbp rRNA operon sequence (which was amplified with primer pair $\mathrm{P} 1 / \mathrm{P} 7$ and included most of the 16S rRNA gene, the 16S-23S rRNA spacer region, and the 5'end of the 23S rRNA gene) from CYE-L phytoplasma with the comparable cloned sequence from CYE-C phytoplasma from Canada was $99.7 \%$ (Table 2). Base substitutions were observed in four positions. Similarity of a $1.5-\mathrm{kbp}$ sequence of $16 \mathrm{~S}$ rDNA from CYE-L phytoplasma with aligned 16S rDNA from CYE-C phytoplasma was $99.7 \%$, and with aligned $16 \mathrm{~S}$ rDNA from ICPh phytoplasma from Italy was $98.8 \%$. These results support the conclusion that phytoplasma CYE-L from clover dwarf-diseased plants in Lithuania is closely related to phytoplasma CYE-C from clover yellow edge-diseased plants in Canada, and that both CYE-C and CYE-L phytoplasmas are related to phytoplasma ICPh from clover phyllody-diseased plants in Italy.

\section{DISCUSSION}

The present study characterizes two phytoplasma taxa associated with diseases in clover and extends their known geographical ranges to the region of northern Europe including Lithuania. The results revealed that, on the basis of extensive RFLP analysis of PCR-amplified rDNA sequences, plants with symptoms of clover phyllody disease in Lithuania were infected by a phytoplasma that was closely related to $\mathrm{CPh}-\mathrm{C}$ phytoplasma in Canada. The results point to clover phyllody-related phytoplasma strains (group 16SrI, subgroup $\mathrm{C}=$ subgroup $\mathrm{I}-\mathrm{C}$ ) as the probable cause of clover phyllody disease in Lithuania, because only these phytoplasma strains were detected in plants with symptoms of this disease, and subgroup I-C strains have consistently been found associated with clover phyllody disease in other regions $(20,31)$. An exception to the association of subgroup I-C strains with clover phyllody disease is the report of a group $16 \mathrm{SrIII}(\mathrm{X}$ disease phytoplasma group) phytoplasma (phytoplasma ICPh) in clover phyllodydiseased plants in Italy (11).

The results also revealed, for the first time (34), that clover dwarf disease in Lithuania was associated with plant infection by a mixture of a CPh-related phytoplasma and a phytoplasma (CYE-L) closely related to CYE-C phytoplasma previously known (22) only in Canada. Identification of phytoplasma CYE-L in clover in Lithuania also extends the known geographical range of subgroup III-B phytoplasma strains. The CYE-L phytoplasma may have played a key role in the development of symptoms of clover dwarf disease because only dwarf-diseased plants contained this phytoplasma. However, it is
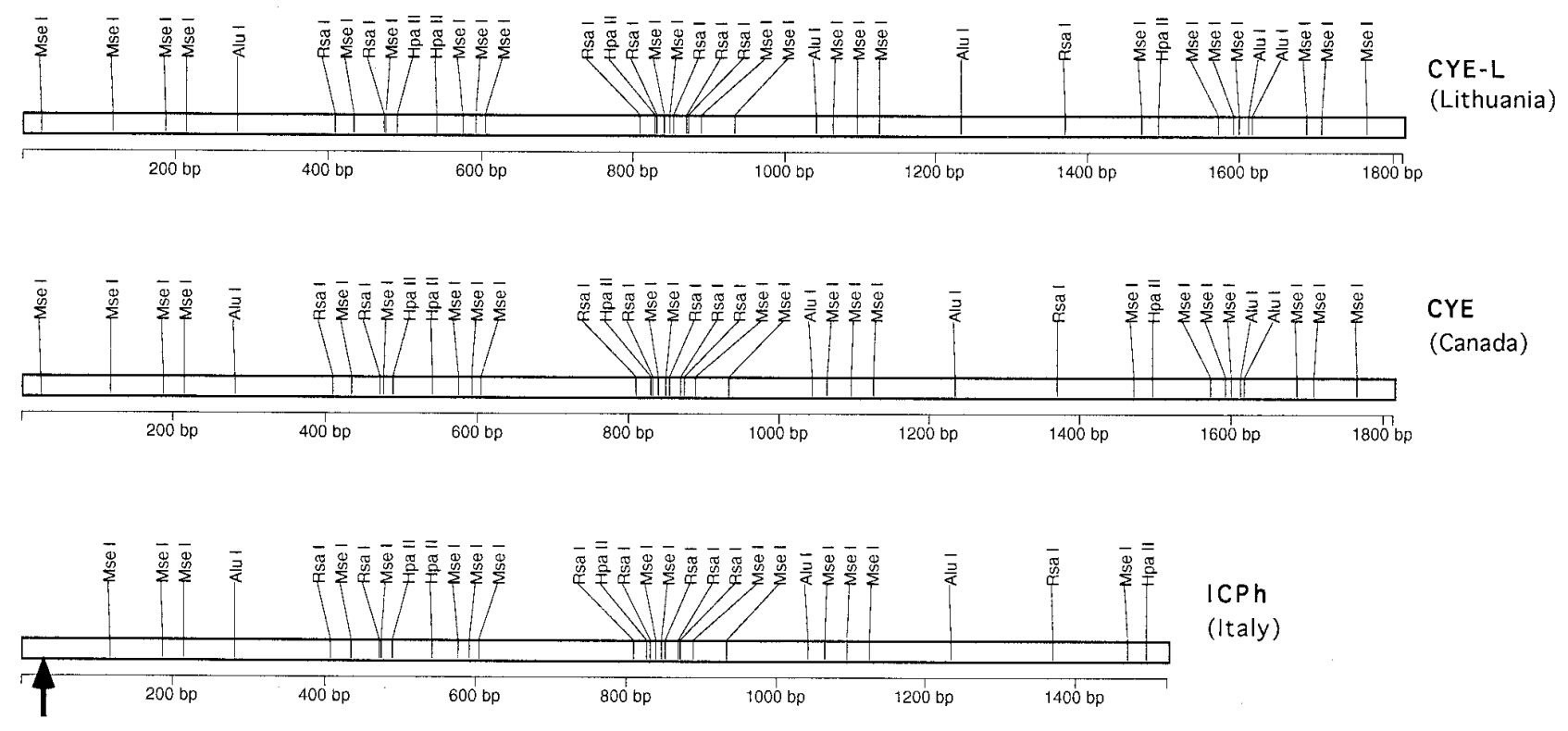

Fig. 5. Analysis of putative restriction sites of phytoplasma rRNA operon sequences. Maps were generated using the MapDraw option of the DNASTAR program (DNASTAR) and manually aligned for comparison of recognition sites for restriction endonucleases. CYE-L, clover yellow edge phytoplasma from Lithuania; CYE-C, clover yellow edge phytoplasma from Canada; and ICPh, Italian clover phyllody phytoplasma. 
not possible to conclude that clover dwarf is induced by CYE-L phytoplasma alone, because both dwarf-diseased plants studied also contained the $\mathrm{CPh}-\mathrm{L}-$ related phytoplasma. Although $\mathrm{CPh}-\mathrm{C}$ and $\mathrm{CYE}-\mathrm{C}$ phytoplasma strains have been reported in Canada $(7,8)$, clover dwarf has not been reported there. This observation may indicate the existence of unusual $\mathrm{CPh}^{-}$or CYE-related phytoplasma strains in Lithuania. However, symptoms of clover yellow edge (8) and of clover phyllody (this article, 7,11) are relatively mild compared to the severe symptoms of clover dwarf. This observation raises the question of a possible synergistic interaction between CPh-L and CYE-L phytoplasmas in the induction of clover dwarf disease. Alternatively, CYE-L may induce symptoms that are more severe than CYE-related strains reported previously. Further studies are needed to resolve whether or not CYE$\mathrm{L}$ phytoplasma alone can induce clover dwarf disease, or whether the severe symptoms of clover dwarf result from a synergistic interaction between $\mathrm{CPh}-\mathrm{L}$ and CYE-L phytoplasmas.

Some of the phytoplasmas known to infect Trifolium spp. appear to be limited in geographical distribution (Table 3), but this impression may be due to paucity of data. For example, clover-infecting and other phytoplasma strains belonging to group 16SrVI (clover proliferation phytoplasma group) have thus far been reported only from North America (17,18,21; Table 3). Prior to the discovery of CYE-L phytoplasma in Lithuania (34, this article), group 16SrIII phytoplasmas in clover had only been reported in Italy and Canada $(4,11,30,32)$. However, group III phytoplasmas have been reported in other plant species in Europe. In Italy, phytoplasma strains probably affiliated with subgroup III-B were also identified in diseased plants of Chrysanthemum leucanthemum, Taraxacum offinale, and Crepis biennis (11). In Germany, a phytoplasma belonging to subgroup III-B was reported in diseased plants of Vaccinium myrtillus $(21,32)$. Although the present study sheds light on group III-related phytoplasmas in clover in the Baltic region, the distribution of CYE$\mathrm{L}$ and other subgroup III-B phytoplasmas in other regions of Europe, including northern and eastern Europe, remains to be determined. For example, it would be of interest to know what phytoplasma or phytoplasmas may be involved in diseases such as clover dwarf, clover stolbur, and parastolbur of clover reported in Czechoslovakia (37). Available data $(11,21,32$, this article) are consistent with the concept that subgroup III-B phytoplasma strains have a widespread European distribution. Their broad plant host range, which includes important agricultural crops, suggests that they could have significant economic impact.

In a study of $T$. pratense and $T$. repens in northern Italy, Firrao et al. (11) found that plants exhibiting symptoms of phyllody contained either $\mathrm{CPh}$ phytoplasma (group I, subgroup C) or ICPh phytoplasma, or contained both phytoplasmas. RFLP and sequence analyses of $16 \mathrm{~S}$ rDNA indicated that ICPh phytoplasma was a member of group 16SrIII (X-disease phytoplasma group). On the basis of nucleotide sequence analyses, we tentatively place $\mathrm{ICPh}$ phytoplasma in subgroup B of group III. Although ICPh phytoplasma was closely related phylogenetically to CYE-C phytoplasma previously reported in Canada, Firrao et al. (11) concluded that ICPh and CYE-C phytoplasmas were distinct from one another. Our comparative analysis of nucleotide sequences of rRNA operon fragments indicated that the CYE-L phytoplasma from Lithuania may also be distinct from the ICPh phytoplasma, but the small difference in $16 \mathrm{~S}$ rDNA sequences indicates that the group 16SrIII subgroup B phytoplasmas reported thus far in Europe should be considered as members of the same rRNA species complex (12) as CYE-C phytoplasma. Nevertheless, it is conceivable that the few base differences among the 16S rRNA genes of these phytoplasmas signal wider distinctions in other conserved genes that could delineate such phytoplasmas as distinct lineages. For this reason, we maintain the designation CYE-L for the group 16SrIII phytoplasma associated with clover dwarf disease in Lithuania, while tentatively classifying this phytoplasma in the CYE-C phytoplasma subgroup (subgroup B of group 16SrIII).

\section{ACKNOWLEDGMENTS}

We thank K. Bottner and K. Kroeger for excellent technical assistance and J. Plaskowitz for preparation of figures.
LITERATURE CITED

1. Amici, A., Gracini, P., Osler, R., and Refatti, E. 1972. Alterazioni a probable eziologia da micoplasmi in varie specie di piante in Italia. Riv. Patol. Veg. Ser. 8:21-50.

2. Begtrup, J., and Thomsen, A. 1984. Mykoplasma-lignende organismer (MLO) og deres udbredelse i Danmark. Tidsskr. Planteavl 88:299-310.

3. Belli, G., Amici, A., and Osler, R. 1972. The mycoplasmas as a cause of plant disease, with reference to the Italian situation. Meded. Fac. Landbouwwet. Rijksuniv. Gent. 37:441-449.

4. Bertaccini, A., Mittempergher, I., and Vibio, M. 1996. Identification of phytoplasmas associated with a decline of European hackberry (Celtis australis). Ann. Appl. Biol. 128:245253.

5. Bowyer, J. W., and Atherton, J. G. 1971 Mycoplasma-like bodies in French bean, dodder, and the leafhopper vector of the legume little leaf agent. Aust. J. Biol. Sci. 24:717729.

6. Bowyer, J. W., Atherton, J. G., Teakle, D. S., and Ahern, G. A. 1969. Mycoplasma-like bodies in plants affected by legume little leaf, tomato big bud, and lucerne witches' broom disease. Aust. J. Biol. Sci. 22:271-274.

7. Chiykowski, L. N. 1962. Clover phyllody virus in Canada and its transmission. Can. J. Bot. 40:397-404.

8. Chiykowski, L. N. 1981. Association of mycoplasma-like organisms with clover yellow edge disease. Can. J. Plant Pathol. 3:139-144.

9. Davis, R. E., Dally, E. L., Gundersen, D. E. Lee, I.-M., and Habili, N. 1997. "Candidatus Phytoplasma australiense," a new phytoplasma taxon associated with Australian grapevine yellows. Int. J. Syst. Bacteriol. 47:262-269.

10. Deng, S., and Hiruki, C. 1991. Genetic relatedness between two non-culturable mycoplasmalike organisms revealed by nucleic acid hybridization and polymerase chain reaction. Phytopathology 81:1475-1479.

11. Firrao, G., Carraro, L., Gobbi, E., and Locci, R. 1996. Molecular characterization of a phytoplasma causing phyllody in clover and other herbaceous hosts in Northern Italy. Eur. J. Plant Pathol. 102:817-822.

12. Fox, G. E., Wisotzkey, J. D., and Jutshuk, P., Jr. 1992. How close is close: 16S rRNA sequence identity may not be sufficient to guarantee species identity. Int. J. Syst. Bacteriol. 42:166-170.

13. Genyte, L., and Staniulis, J. 1975. Yellows type diseases of clover associated with mycoplasmalike organisms, and their transmission by Aphrodes bicinctus. In: Virological Investigations in the Far East. Virusologicheskie Issledovanija na Dalnem Trudy Biologo-Pochyennogo Instituta Vostoke 28(131):165170. (In Russian)

14. Giannotti, J., Devauchelle, G., and Vago, C. 1968. Microorganisme de type mycoplasma chez une cicade et une plante infectée par phyllodie. C.R. Acad. Sci. Ser. D 266:21682170 .

Table 3. Phytoplasmas associated with diseases in clover (Trifolium spp.) in Europe and North America

\begin{tabular}{llll}
\hline Phytoplasma strain & \multicolumn{1}{c}{ Associated disease (location) } & \multicolumn{1}{c}{ 16S rRNA group (subgroup) } & References \\
\hline CPh-L & Clover phyllody (Lithuania) & Aster yellows group, group 16SrI (C) & This article \\
CYE-L & Clover dwarf (Lithuania) & X-disease group, group 16SrIII(B) & This article \\
CPh-C & Clover phyllody (Canada) & Aster yellows group, group 16SrI (C) & 22 \\
CYE-C & Clover yellow edge (Canada) & X-disease group, group 16SrIII (B) & 22 \\
CP-C & Clover proliferation (Canada) & Clover proliferation group, group 16SrVI (A) & 22 \\
ICPh & Clover phyllody (Italy) & X-disease group, group 16SrIII (subgroup unspecified) & 11 \\
CPh-I & Clover phyllody (Italy) & Aster yellows group, group 16SrI (C) & 11 \\
ParaSTOL & Clover parastolbur (Czechoslovakia) & unclassified & 37 \\
CDw-Cz & Clover dwarf (Czechoslavakia) & unclassified & 37 \\
\hline
\end{tabular}


15. Gundersen, D. E., and Lee, I.-M. 1996. Ultrasensitive detection of phytoplasmas by nested PCR assays using two universal primer pairs. Phytopathol. Mediterr. 35:144-151.

16. Gundersen, D. E., Lee, I.-M., Rehner, S. A., Davis, R. E., and Kingsbury, D. T. 1994. Phylogeny of mycoplasmalike organisms (phytoplasmas): a basis for their classification. J. Bacteriol. 176:5244-5254.

17. Jomantiene, R., Davis, R. E., Dally, E. L., Maas, J. L., and Postman, J. D. 1998. The distinctive morphology of 'Fragaria multicipita' is due to phytoplasma. HortScience 33:1069-1072.

18. Jomantiene, R., Davis, R. E., Maas., J., and Dally, E. L. 1998. Classification of new phytoplasmas associated with diseases of strawberry in Florida, based on analysis of $16 \mathrm{~S}$ rRNA and ribosomal protein gene operon sequences. Int. J. Syst. Bacteriol. 48:269-277.

19. Kleinhempel, H., Muller, H., and Spaar, D. 1972. Isolierung und Kultivierung von Mycoplasmatales aus Weissklee mit Blutenvergrunungssymptomen. Arch. Pflanzenschutz 8:361-370.

20. Lee, I.-M., Gundersen, D. E., Hammond, R. W., and Davis, R. E. 1994. Use of mycoplasmalike organism (MLO) group-specific oligonucleotide primers for nested-PCR assays to detect mixed-MLO infections in a single host plant. Phytopathology 84:559-566.

21. Lee, I.-M., Gundersen-Rindal, D. E., Davis, R. E., and Bartoszyk, I. M. 1998. Revised classification scheme of phytoplasmas based on RFLP analysis of 16S rRNA and ribosomal protein gene sequences. Int. J. Syst. Bacteriol. 48:1153-1169.

22. Lee, I.-M., Hammond, R. W., Davis, R. E., and Gundersen, D. E.. 1993. Universal amplification and analysis of pathogen 16S rDNA for classification and identification of mycoplasmalike organisms. Phytopatholgy 83:834-842.

23. Leont'jeva, G. V., Leont'jeva, J. A., and Makeev, V. A. 1978. Distribution and yield reduction of alfalfa witches' broom in Kuibyshev district. Breed. Plant Prot. 1978:18-21. (In Russian).
24. Maillet, P. L., Gourret, J. P., and Hamon, C. 1968. Sur la présence de particules de type Mycoplasme dans le liber de plante atteintes de maladies du type "jaunisse" (Aster Yellow, Phyllodie du Trèfle, Stolbur de la Tomate) et sur la parente ultrastructurale de ces particules avec celles trouvées chez divers Insectes Homoptères. C.R. Hebd. Seances Acad. Paris Ser. D 266:2309-2311.

25. Musil, M. 1961. Transmission of phyllody virus by means of the leafhopper Euscelis plebejus (Fallen). Biol. Plant. (Praha) 3:2933.

26. Ploaie, P. G., Granados, R. G., and Maramorosch, K. 1968. Mycoplasma-like structures in periwinkle plants with Crimean yellows, European clover dwarf, stolbur, and parastolbur. (Abstr.) Phytopathology 58:1063.

27. Ploaie, P. G., and Maramorosch, K. 1969. Electron microscopic demonstration of particles resembling mycoplasma or psittacosislymphogranuloma-trachoma group in plants infected with European yellows-type diseases. Phytopathology 59:536-544.

28. Ploaie, P. G., Misiga, S., and Musil, M. 1961. Rozsirenic parastoburu na Slovensku. Biologia (Bratislava) 16:178-183.

29. Ploaie, P. G., Petre, Z., and Ionica, M. 1977. Identificarea unor boli din grupul proliferarii, clorozelor si nanismului la plante, asociate cu micoplasma in Romania. Ann. Inst. Cercetari Pentru Protectia Plantelor 12:17-25.

30. Prince, J. P., Davis, R. E., Wolf, T. K., Lee, I.M., Mogen, B. D., Dally, E. L., Bertaccini, A., Credi, R., and Barba, B. 1993. Molecular detection of diverse mycoplasmalike organisms (MLOs) associated with grapevine yellows and their classification with aster yellows, Xdisease, and elm yellows MLOs. Phytopathology 83:1130-1137.

31. Schneider, B., Marcone, C., Kampmann, M., Ragozzino, A., Lederer, W., Cousin, M. T., and Seemüller, E. 1997. Characterization and classification of phytoplasmas from wild and cultivated plants by RFLP and sequence analysis of ribosomal DNA. Eur. J. Plant Pathol. 103:675-686.
32. Seemüller, E., Schneider, B., Mäurer, R Ahrens, U., Daire, X., Kison, H., Lorenz, K. H., Firrao, G., Avinent, L., Sears, B. B., and Stackebrandt, E. 1994. Phylogenetic classification of phytopathogenic mollicutes by sequence analysis of $16 \mathrm{~S}$ ribosomal DNA. Int. J. Syst. Bacteriol. 44:440-446.

33. Smart, C. D., Schneider, B., Blomquist, C. L., Guerra, L. J., Harrison, N. A., Ahrens, U., Lorenz, K. H., Seemüller, E., and Kirkpatrick, B. C. 1996. Phytoplasma-specific PCR primers based on sequences of $16 \mathrm{~S}-23 \mathrm{~S}$ rRNA spacer region. Appl. Environ. Microbiol. 62:29882993.

34. Staniulis, J., Davis, R. E., Jomantiene, R. Kalvelyte, A., and Dally, E. L.. 1999. Phytoplasmas associated with clover phyllody and clover dwarf diseases in Lithuania. (Abstr.) Phytopathology 89:S102.

35. Staniulis, J., and Genyte, G. 1974. Distribution, transmission and biology of clover yellows type disease caused by mycoplasma organisms. I. Mycoplasma-like organisms discovered in association with dwarfing and chlorosis of leaves. Lietuvos TSR Mokslu Akademijos Darbai, C ser. I(65):3-9.

36. Valenta, V., Misiga, S., and Musil, M. 1961. Rozsirenie parastolburu na Slovensku. Biologia (Bratislava) 16:178-183.

37. Valenta, V., and Musil, M. 1963. Investigations on European yellows-type viruses. II The clover dwarf and parastolbur viruses. Phytopathol. Z. 47:38-65.

38. Valenta, V., and Musil, M. 1964. Some data on the distribution of yellows-type viruses in Slovakia. Pages 270-271 in: Plant Virology, Proc. 5th Conf. Czechoslovak Plant Virol. Prague.

39. Valenta, V., Musil, M., and Misiga, S. 1961. Investigation on European yellows-type viruses. I. The stolbur virus. Phytopathol. Z 42:1-38.

40. Vibio, M., Bertaccini, A., Lee, I.-M., Davis, R. E., and Clark, M. F. 1996. Differentiation and classification of aster yellows and related European phytoplasmas. Phytopathol. Mediterr. 35:33-42. 